
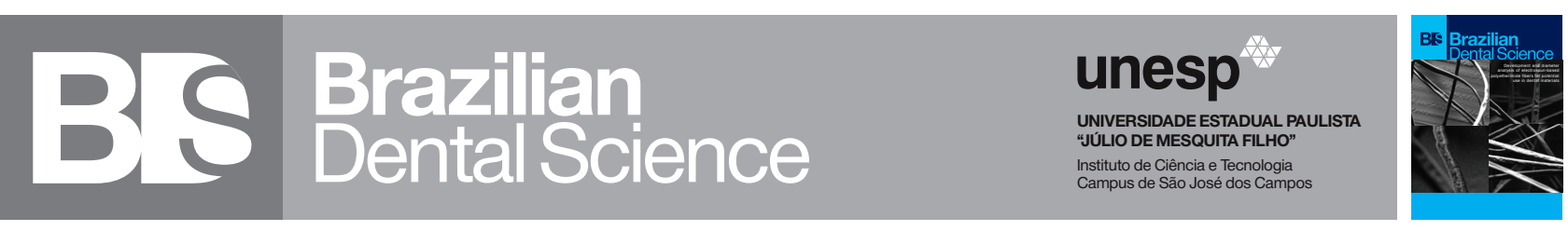

\title{
Study of crystallization, microstructure and mechanical properties of lithium disilicate glass-ceramics as a function of the sintering temperature
}

\author{
Estudo da cristalização, microestrutura e propriedades mecânicas de uma vitrocerâmica de dissilicato de lítio em função \\ da temperatura de sinterização \\ Dayana Campanelli de MORAIS ${ }^{1}$, Matheus Ferreira Theotonio SANTOS ${ }^{2}$, Tiago Moreira Bastos CAMPOS $^{3}$, Eliandra de Sousa \\ TRICHÊS ${ }^{2}$, Alexandre Luiz Souto BORGES ${ }^{1}$ \\ 1 - São Paulo State University (Unesp), Institute of Science and Technology, São José dos Campos, Department of Dental Materials and \\ Prosthodontics, SP, Brazil. \\ 2 - Department of Bioceramics, Federal University of São Paulo (Unifesp), São José dos Campos, SP, Brazil. \\ 3 - Aeronautics Technological Institute (ITA), São José dos Campos, SP, Brazil.
}

\section{ABSTRACT}

Objective: The purpose of the present study was to synthesize and characterize lithium disilicate glass-ceramics through the $\mathrm{Li}_{2} \mathrm{O}-\mathrm{SiO}_{2}$ system for determining the most satisfactory sintering parameter by evaluating the crystalline composition, microstructure and mechanical properties. Material and methods: The glass-ceramics were prepared from a glass precursor by means of the melting/cooling technique with a composition of $33.33 \mathrm{Li}_{2} \mathrm{O}$ and $66.67 \mathrm{SiO}_{2}$ (mol.\%). The specimens were compressed by the uniaxial pressing technique and three different thermal treatments were used for sintering: $850{ }^{\circ} \mathrm{C}$ (Group 1), $900{ }^{\circ} \mathrm{C}$ (Group 2), and $950{ }^{\circ} \mathrm{C}$ (Group 3), which were determined based on the differential scanning calorimetry (DSC) result. The glass-ceramics were characterized by X-ray diffraction (XRD), scanning electron microscopy (SEM), Archimedes method, microhardness and biaxial flexural strength analyses. Results: The results regarding XRD predominantly showed lithium disilicate phase for all the heat treatments performed. Moreover, grains with a needle form were more predominantly observed in the SEM images for Group 3, as well as a higher densification and consequently higher mechanical properties. In contrast, Group 1 presented the lowest mechanical properties and

\section{RESUIMO}

Objetivo: O presente estudo teve como objetivo sintetizar e caracterizar uma vitrocerâmica de dissilicato de lítio através do sistema $\mathrm{Li}_{2} \mathrm{O}-\mathrm{SiO}_{2}$ para determinar o parâmetro de sinterização mais satisfatório através da avaliação da composição cristalina, microestrutura e propriedades mecânicas. Material e Métodos: As vitrocerâmicas foram preparadas a partir de um vidro precursor pelo método fusão/resfriamento utilizando a composição de $33.33 \mathrm{Li2O} \mathrm{e} 66.67 \mathrm{SiO}_{2}$ (mol.\%). As amostras foram prensadas utilizando uma técnica de prensagem uniaxial e três tratamentos térmicos diferentes foram utilizadas para sinterização: $850^{\circ} \mathrm{C}$ (Grupo 1), $900^{\circ} \mathrm{C}$ (Grupo 2), e $950^{\circ} \mathrm{C}$ (Grupo 3), que foram determinados através do resultado da análise diferencial de calorimetria. As vitrocerâmicas foram caracterizadas através das análises de difração de raios X (DRX), microscopia eletrônica de varredura (MEV), métodos de Arquimedes, microdureza e ensaio de flexão biaxial. Resultados: Os resultados de DRX mostraram predominantemente a fase de dissilicato de lítio para todos os tratamentos realizados. Além disso, grãos com forma agulhada foram mais predominantemente observados por MEV no grupo 3, assim como uma densificação maior e consequentemente valores maiores das propriedades mecânicas. Em contraste, o grupo 1 apresentou os menores valores de propriedades mecânicas e densificação, e também 
densification, as well as the highest porosity. Conclusion: The present study demonstrated how extremely important it is to follow the heat treatment recommended by the manufacturers of ceramics, including time and temperature, which possess direct effects in the crystalline phase formation, as well as in the material's microstructure and mechanical properties.

\section{KEYWORDS}

Crystallization; Glass-ceramics; Lithium disilicate.

\section{INTRODUCTION}

$\mathrm{T}$ here has been an increase in research in recent years related to ceramic materials as a biomaterial often used in oral rehabilitations due to their versatility in replacement function and form to the dental element [1-4]. In the range of ceramics commercially available, lithium disilicate (Li2Si2O5) glass-ceramic has received a great deal of interest predominantly due to its mechanical properties and high potential to be used as dental materials $[5,6]$.

Glass-ceramics are normally obtained by the crystallization of suitable glass through controlled heat treatments, which transforms the vitreous parent glass into a uniform microcrystalline ceramic after internal or external nucleation [7]. $\mathrm{Li}_{2} \mathrm{O}-\mathrm{SiO}_{2}$ is a binary system, which has been widely studied involving various fabrication methods; one such method is through the sintering of glass frits $[3,5,8]$, which can form lithium disilicate phase after a controlled and slow crystallization process. Understanding and controlling glass crystallization mechanisms has great scientific and technological importance, as it allows internal regulation as well as oriented development of the grains without producing micro-cracks or porosity, thereby providing satisfactory mechanical strength and translucency which are paramount features for glass-ceramics [2]. a maior porosidade. Conclusão: O presente estudo demonstrou como é extremamente importante seguir o tratamento térmico recomendado pelos fabricantes de cerâmica, incluindo tempo e temperatura, que possuem efeitos diretos na formação da fase cristalina, assim como na microestrutura do material e propriedades mecânicas.

\section{PALAVRAS-CHAVE}

Cristalização; Vitrocerâmicas; Dissilicato de lítio.

Some studies have reported that the resulting crystal form and phase after the sintering process has a paramount influence on the crystalline structure and mechanical properties achieved by the material, which are dependent on the composition of the parent glass as well as on the sintering temperature and time $[6,9,10]$. In addition, it has been reported that the final temperature has a major impact on the sintering process and has therefore gained much attention [11]. In order to achieve a lithium disilicate phase, the sintering temperatures in previous studies were less than $900{ }^{\circ} \mathrm{C}[3,5,12,13]$, which is much lower than the melting temperature $\left(\mathrm{T}_{\mathrm{m}}\right)$, while the likely consequences of a higher final temperature for the binary system are still not well known.

In view of the above, this study aimed to synthesize and to determine the most satisfactory sintering treatment to obtain an experimental lithium disilicate glass-ceramic from the binary $\mathrm{Li}_{2} \mathrm{O}-\mathrm{SiO}_{2}$ system (33.33 $\left.\mathrm{Li}_{2} \mathrm{O} .66 .67 \mathrm{SiO}_{2}, \mathrm{~mol} \%\right)$. The crystallization temperature varied from 850 ${ }^{\circ} \mathrm{C}$ to $950^{\circ} \mathrm{C}$, which is near $\mathrm{Tm}$, aiming to disclose the effects of these different temperatures on crystallization, microstructure and mechanical properties of the studied glass-ceramics. 


\section{MATERIAL AND METHODS}

\section{Preparation and characterization of $\mathrm{SiO}_{2}-\mathrm{Li}_{2} \mathrm{O}$ glass}

First, $\mathrm{Li}_{2} \mathrm{CO} 3$ and $\mathrm{SiO}_{2}$ (Sigma-Aldrich, Brazil) powders were weighed in a stoichiometric composition (33.33 $\mathrm{Li}_{2} \mathrm{O} .66 .67 \quad \mathrm{SiO}_{2}, \mathrm{~mol} \%$ ), mixed in a mill (Marconi, MA 500, Brazil) for $2 \mathrm{~h}$ for homogenization. Next, the mixture was introduced into a ZAS crucible (zirconiaalumina-silica) and melted in a laboratory furnace (Fortelab, MEV-1700/V, Brazil), which was performed in two steps: $720^{\circ} \mathrm{C}$ for $15 \mathrm{~min}$ with heating of $10{ }^{\circ} \mathrm{C} / \mathrm{min}$, and then $1400{ }^{\circ} \mathrm{C}$ for $2 \mathrm{~h}$ with heating increments of $5{ }^{\circ} \mathrm{C} / \mathrm{min}$. The first step removed the $\mathrm{CO}_{2}$ gas released in the decarbonation reaction, while the second step promoted glass melting and its homogenization. After the end of the second step, the molten glass was quickly spilled into water to obtain the frit, which was collected, dried and milled in a planetary mill (Fritsch, Pulverisette 5, Germany) for $30 \mathrm{~min}$ with a rotation of $220 \mathrm{rpm}$. Zirconia balls (10 and $20 \mathrm{~mm}$ of diameter) were used in a weight ratio of $1: 10$ between the glass powder and the zirconia balls, respectively. The $\mathrm{SiO}_{2}-\mathrm{Li}_{2} \mathrm{O}$ glass powder was subsequently passed through a sieve, aiming to obtain a particle size of less than $73 \mu \mathrm{m}$ (200 mesh). Moreover, a binder (5\% volume/volume solution of polyvinyl alcoholPVA) was added to the glass powder and the new mixture was passed through the sieve (200 mesh) again to ensure that the formed granules were less than $73 \mu \mathrm{m}$.

\section{X-ray diffraction and Differential scanning calorimetry}

The X-ray diffraction (XRD) technique was performed by a diffractometer (Shimadzu $\mathrm{XRD7000}, \mathrm{CuK \alpha}$ radiation, $2 \theta=10-70^{\circ}, 40 \mathrm{~mA}$, $40 \mathrm{kV}$ ) to analyze and attest that the obtained glass was amorphous. The glass transition, crystallization and melting temperatures of the glass powder were determined by differential scanning calorimetry (DSC). The analysis was performed using the simultaneous thermal analyzer (STA 449 F3 Jupiter ${ }^{\circledR}$-NETZSCH) in a nitrogen atmosphere, with a heating rate of 10 ${ }^{\circ} \mathrm{C} / \mathrm{min}$ to $1200{ }^{\circ} \mathrm{C}$, and $0.03 \mathrm{~g}$ of ground glass powder was used for each analysis.

Preparation and characterization of lithium disilicate glass-ceramic $\left(\mathrm{Li}_{2} \mathrm{Si}_{2} \mathrm{O5}\right)$

The powder was compacted into disc form in a hydraulic press (Marcon, MPH10, Brazil) by uniaxial pressing with a pressure of $14.7 \mathrm{MPa}$ applied for 1 minute, using $0.4 \mathrm{~g}$ per specimen in a matrix with $15 \mathrm{~mm}$ of diameter. The mold was lubricated with stearic acid to reduce the friction between the matrix and the glass powder particles before each uniaxial pressing.

The thermal treatments were performed based on the temperatures corresponding to the structural modifications obtained by the DSC in order to achieve the lithium disilicate phase formation. The heat treatments were performed in a furnace (JUNG, LF00914, Brazil). the specimens were polished with $\mathrm{SiC} \# 400,800$ and 1200 according to the ISO standard CD 6872, and attained final dimensions of $12 \mathrm{~mm}$ in diameter and $1.2 \mathrm{~mm}$ thickness.

The crystalline phases present in the lithium disilicate glass-ceramics were also determined by a diffractometer (the same mentioned previously) and one disc of each group was used. The JCPDS International Center for Diffraction Data assisted in identifying the crystalline phases.

The microstructure was analyzed by scanning electron microscopy (SEM, FEI, Czech Republic). The discs were coated with gold by sputtering (EMITECH SC7620 Sputter Coater, East Sussex, United Kingdom), with one disc from each group being selected and prepared with 10\% hydrofluoric acid for 20 seconds (on each surface).

Density and apparent porosity measurements were performed on three specimens of each lithium disilicate glass ceramic 
group using the Archimedes method in water. The sample mass measurements were carried out on a scale under various conditions: dry, immersed, and wet or saturated in water. The density and apparent porosity were calculated by the following equations ( 1 and 2 ):

$$
\begin{array}{ll}
\text { Equation 1 } & D=\frac{M d}{M w-M i} \times \rho_{\text {water }} \\
\text { Equation 2 } & P=\frac{M w-M d}{M w-M i} \times 100
\end{array}
$$

Where $\mathrm{D}$ is the density and $\mathrm{P}$ is the porosity. Md is the dry mass; Mw is the wet mass and Mi is the immersed mass.

Regarding hardness, five Vickers indentations were performed in the center of 5 discs of each group in order to create a defect. The specimens were indented with $1 \mathrm{~kg}$ for 12 seconds, and then the size of the indentation was measured.

Next, the biaxial flexural strength (BFS) test was performed in a universal testing machine (Emic DL, São José dos Pinhais, PR, Brazil). The specimens were positioned over three support spheres ( $3 \mathrm{~mm}$ in diameter) which were equally spaced at a circumference of $10 \mathrm{~mm}$. The load was applied by a circular flat piston $(1.5 \mathrm{~mm}$ in diameter) at $1 \mathrm{~mm} / \mathrm{min}$ until the failure. Fifteen specimens from each group were tested, and a piece of adhesive tape (3M ESPE) was fixed to their compression side to minimize defects caused by the metallic tip, as well as to keep the fragments in position. The BFS of the monolithic discs was calculated according to equation 3 :

$$
\text { Equation } 3 \quad S=-0.2387 P(X-Y) / d^{2}
$$

Where $\mathrm{S}$ is the maximum tensile stress (MPa), $\mathrm{P}$ is the total load applied to cause the fracture $(\mathrm{N})$, and $\mathrm{d}$ is the specimen thickness at the origin of the fracture $(\mathrm{mm}) . \mathrm{X}$ and $\mathrm{Y}$ are parameters related to the elastic properties of the material (Poisson's ratio and elastic modulus).

\section{Statistical Analysis}

The data were analyzed individually in one-way ANOVA tests, and Post hoc multiple comparisons were performed using Tukey's test at $\alpha=5 \%$.

\section{RESULTS}

\section{Characterization of $\mathrm{SiO}_{2}-\mathrm{Li}_{2} \mathrm{O}$ glass}

The frit obtained from the melting/cooling method was an amorphous glass which was confirmed by the presence of a halo in Figure 1. Moreover, Figure 2 shows the thermal analysis results of $\mathrm{SiO}_{2}-\mathrm{Li}_{2} \mathrm{O}$ glass. The glass transition $\left(\mathrm{T}_{\mathrm{g}}\right)$ occurred at $470{ }^{\circ} \mathrm{C}$, the crystallization temperature $\left(\mathrm{T}_{\mathrm{c}}\right)$ was the highest exothermic peak which occurred at $580{ }^{\circ} \mathrm{C}$, and the melting temperature $\left(\mathrm{T}_{\mathrm{m}}\right)$ occurred at $1040{ }^{\circ} \mathrm{C}$. Thus, the heat treatment was planned (Table I) according to these data, using the $1^{\text {st }}$ temperature step for binder elimination (PVA), the $2^{\text {nd }}$ step for nucleation and the crystallization process, and the $3^{\text {rd }}$ step for crystallization and densification. A heating rate of $2{ }^{\circ} \mathrm{C} / \mathrm{min}$ was used in the 1 st step and then increased to $5{ }^{\circ} \mathrm{C} / \mathrm{min}$ in the $2^{\text {nd }}$ and $3^{\text {rd }}$ steps.

\begin{tabular}{|c|c|c|c|c|}
\hline & & Group1 & Group2 & Group 3 \\
\hline $300^{\circ} \mathrm{C} / \mathrm{hh}$ & $580^{\circ} \mathrm{C} / \mathrm{hh}$ & $850^{\circ} \mathrm{C} / 3 \mathrm{~h}$ & $900^{\circ} \mathrm{C} / 3 \mathrm{~h}$ & $950^{\circ} \mathrm{C} / 3 \mathrm{~h}$ \\
\hline${ }^{1 s t}$ step & $2^{\text {nd }}$ step & & $3^{\text {rd }}$ step & \\
\hline
\end{tabular}

Table I - Thermal treatments used to obtain the experimental lithium disilicate glass-ceramic

The crystalline phases of lithium disilicate $\left(\mathrm{Li}_{2} \mathrm{Si}_{2} \mathrm{O}_{5}\right.$, JCPDS 00-040-0376) and quartz (Figure 3) were identified by XRD analysis. Next, SEM micrographs (Figure 4) depicted the needle grains most clearly for Group 3 (Figure 4-C), as well as showing a better densified structure. On the other hand, the structure was less dense when the material was sintered at lower temperatures such as $850^{\circ} \mathrm{C}$ (Figure 4-A) and $900^{\circ} \mathrm{C}$ (Figure 
4-B), and the grains possessed a subtle needle format.

All the treatments presented statistical differences in relation to density, apparent porosity, hardness and BFS. Group 3 achieved the highest values for density, hardness and BFS results (Table II), while Group 1 reached the lowest values due to its higher porosity.

Table II - Means values and SD of porosity, density, hardness and $\mathrm{BFS}$ for $\mathrm{SiO}_{2}-\mathrm{Li}_{2} \mathrm{O}$ glass-ceramics after heat treatments

\begin{tabular}{|c|c|c|c|}
\hline & $\begin{array}{l}\text { Group 1 } \\
\left(850^{\circ} \mathrm{C}\right)\end{array}$ & $\begin{array}{l}\text { Group } 2 \\
\left(900^{\circ} \mathrm{C}\right)\end{array}$ & $\begin{array}{l}\text { Group } 3 \\
\left(950^{\circ} \mathrm{C}\right)\end{array}$ \\
\hline Porosity (\%) & $33.89(0.37) \mathrm{A}$ & $27.67(0.36) \mathrm{B}$ & $11.30(0.40) \mathrm{C}$ \\
\hline Density $\left(\mathrm{g} / \mathrm{cm}^{3}\right)$ & $1.61(0.01) \mathrm{C}$ & $1.74(0.01) \mathrm{B}$ & $2.11(0.01) A$ \\
\hline Hardness (HV) & $43.24(5.87) \mathrm{C}$ & $81.50(5.50) \mathrm{B}$ & 249.6 (12.9) A \\
\hline BFS(MPa) & $43.69(11.25) \mathrm{C}$ & 90 (11.92) B & $179.99(7.72) \mathrm{A}$ \\
\hline
\end{tabular}

Data is presented by means (SD). Different letters show statistical differences.

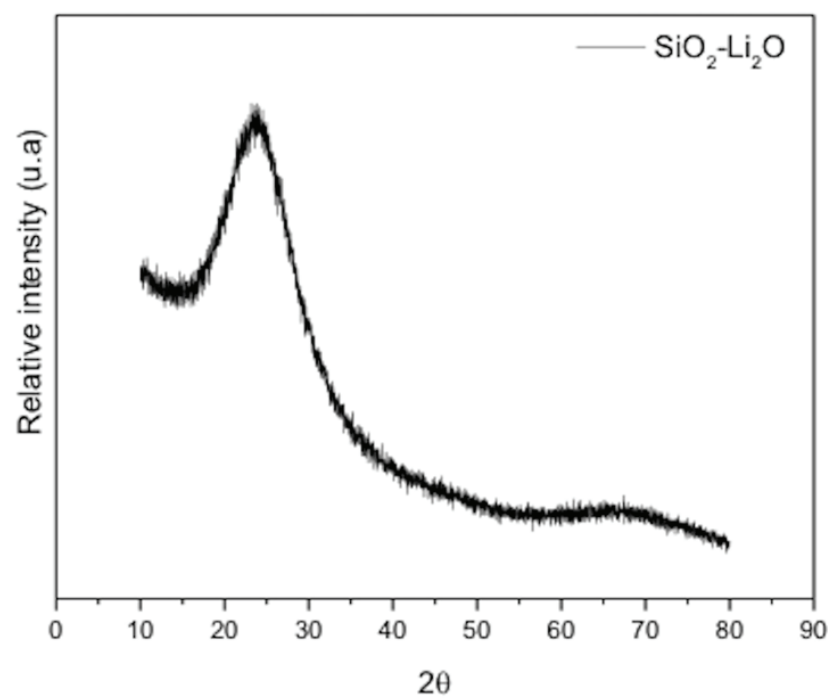

Figure 1- XRD pattern of the SiO2-Li2O glass obtained from melting/cooling method.

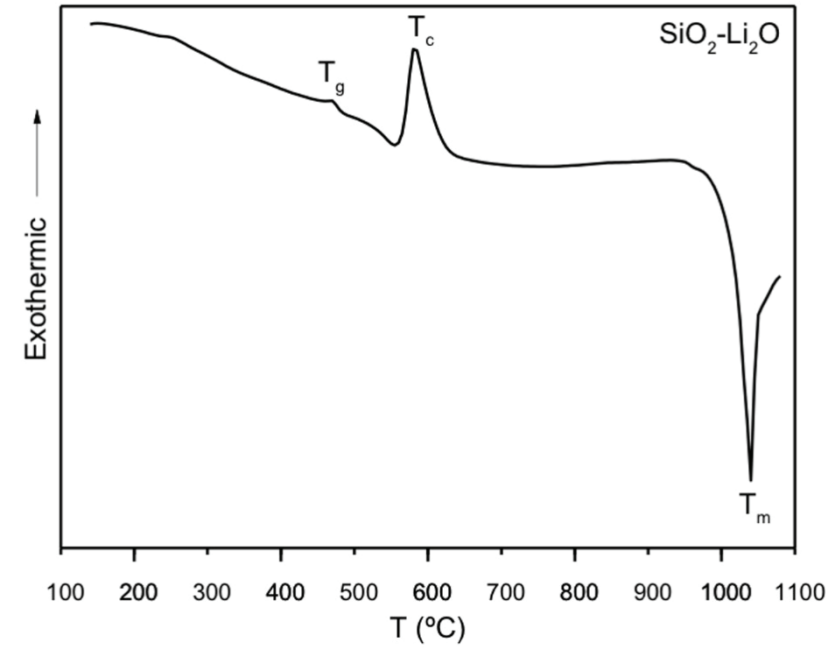

Figure 2 - DSC curve of the $\mathrm{SiO}_{2}-\mathrm{Li}_{2} \mathrm{O}$ glass.

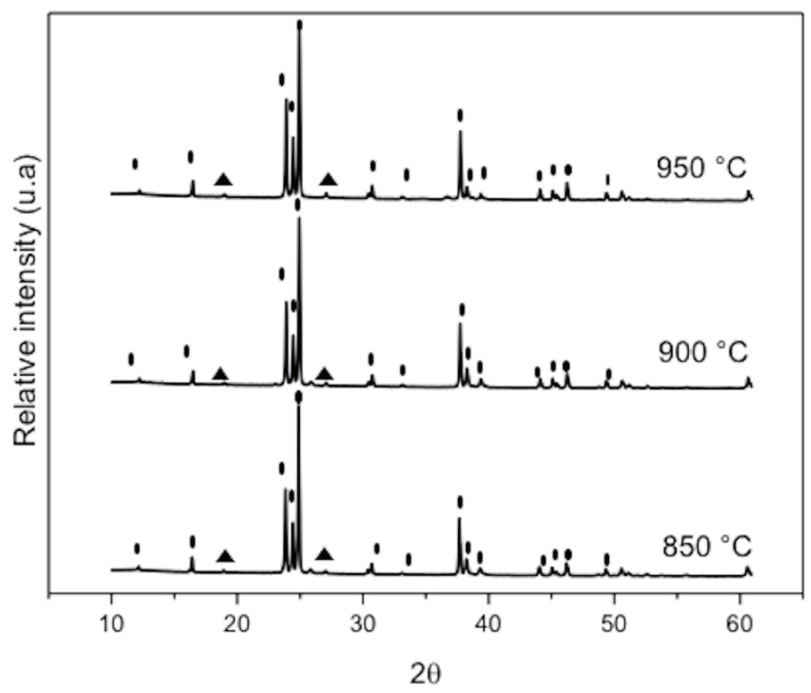

Figure 3 - XRD patterns of the $\mathrm{SiO}_{2}-\mathrm{Li}_{2} \mathrm{O}$ glass-ceramics after heat treatment. Lithium • disilicate, $\triangle$ Quartz. 

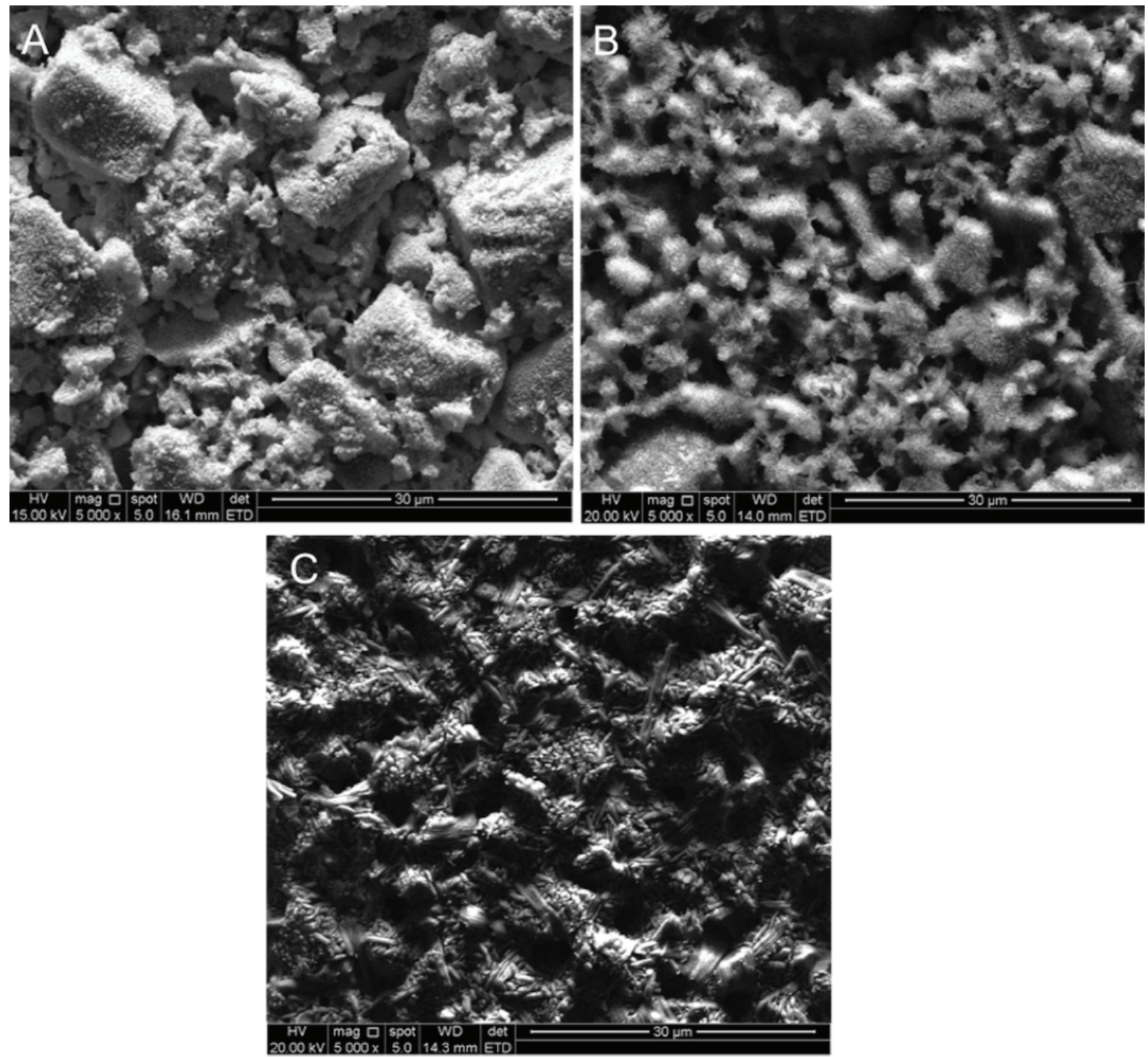

Figure 4 - SEM micrographs of the $\mathrm{SiO}_{2}-\mathrm{Li}_{2} \mathrm{O}$ glass-ceramics after heat treatments. A) Group $\left.1\left(850{ }^{\circ} \mathrm{C}\right), \mathrm{B}\right) \mathrm{Group} 2\left(900{ }^{\circ} \mathrm{C}\right)$ and $\left.\mathrm{C}\right)$ Group $3\left(950^{\circ} \mathrm{C}\right)$.

\section{DISCUSSION}

The present study synthesized an experimental glass-ceramic derived from the $\mathrm{Li}_{2} \mathrm{O}-\mathrm{SiO}_{2}$ system aiming to study the sintering process, and to evaluate the microstructure, densification and mechanical properties of the new material. Regardless of the analysis, all studied temperatures presented significant differences. Group 3, which was the highest temperature analyzed, achieved the highest mechanical properties, while Group 1 showed the lowest mechanical properties and highest apparent porosity.

The nucleation and crystal growth phases are of primary importance for the microstructural development of glass-ceramics due to their direct interference on the properties of the new material $[14,15]$. A sequence of phase changes 
takes place during the conversion of glass to a final ceramic material with a microstructure of interlocking crystals [16]. The nucleation process is the key to control and predict the glass devitrification, which is done by a heat treatment above the glass transition temperature $\mathrm{T}_{g}$ [17]. The $\mathrm{T}_{\mathrm{g}}$ found in this study occurred at $470{ }^{\circ} \mathrm{C}$ and determined the second step of the heat treatment, which was maintained for one hour to promote a slow nucleation. This stage was followed by the third stage at a higher temperature at which crystal growth took place [18]. It has been reported that the crystal growth rate for lithium disilicate crystals is a function of the reciprocal temperature value [13], which could be observed by the micrographs, in which the lithium disilicate crystals inevitably increased by increasing the sintering temperature. Thus, the use of a final sintering temperature of $950^{\circ} \mathrm{C}$ for the presented system was safe, not causing any material melting, and was also able to improve the crystal growth.

Moreover, it has been reported that temperature and time are directly related to phase transformations in the synthesis of ceramics [16,19]. The lithium metasilicate $\left(\mathrm{Li}_{2} \mathrm{SiO}_{3}\right.$ ) phase grows fast after nucleation and completely decomposes at $820{ }^{\circ} \mathrm{C}[3,20]$, and is a precursor for lithium disilicate crystallization [21]. Thus, the lowest temperature used for the crystallization of the glass-ceramics was at $850^{\circ} \mathrm{C}$, since the aim was to achieve the lithium disilicate phase for all groups as it crystalizes easily, and the availability of reliable thermodynamic data makes it a preferred model system for studying glass-ceramics [22,23].

In relation to the micrographs, increasing the temperature resulted in more noticeable needle-like particles of lithium disilicate, suggesting that high temperatures are preferable for strengthening the material achieved by a dense crystal microstructure. The mechanical properties analyzed were consequently improved, including the biaxial flexural strength (BFS), which remarkably increased from $51 \mathrm{MPa}$ to 160 MPa in comparing Groups 1 and 3, respectively. Moreover, the final temperature also had a major impact on the densification process $[8,11]$ and hardness, which significantly increased when the temperature also increased. These findings can be mainly attributed to efficient sintering behavior, the high relative density, and also the interlocking structure with rod-shaped crystals homogenously embedded in the matrix, which plays an important role in hindering crack propagation and elevating flexural strength $[5,8]$.

Additionally, the flexural strength characterizes the maximum stress level supported by the material under flexural stress, thus providing the most clinically relevant mechanical specification for brittle dental ceramics [14]. In a previous study, Yuan et al. 2013 [14] reported that crystals with a larger size may provide stronger mechanical strength by developing a more organized microstructure. Indeed, an increase in the crystal size and flexural strength was observed when the sintering temperature increased, agreeing with a previous study [24], which reported a similar finding and also observed a decrease in the open porosity of the lithium disilicate glass-ceramics. Likewise, the porosity of the presented glass-ceramic was also abruptly reduced by an increase of $100{ }^{\circ} \mathrm{C}$, which can be directly related to the crystal shape that was transformed into rod-shaped crystals at higher sintering temperature.

Therefore, this study analyzed the effects of heat treatments on the crystalline composition, microstructure, porosity, density, hardness and biaxial flexural strength of glassceramics of the $\mathrm{Li}_{2} \mathrm{O}-\mathrm{SiO}_{2}$ system. The studied temperatures presented no significant effect on the composition of the crystalline phases of the glass-ceramics. However, there was a significant effect on the crystal size, apparent porosity and density, with higher temperatures resulting in larger crystals, as well as in a denser and less porous material, without melting the material. 
Likewise, higher hardness and BFS values were also evaluated, which significantly increased when the temperature also increased. However, this study presented some limitations such as the use of a simple binary system and the pressureless sintering, which could be modified in further studies in order to obtain glass-ceramics with higher mechanical properties and an even denser microstructure.

\section{CONCLUSION}

The effect of sintering temperatures on the lithium disilicate glass-ceramics showed that its morphology and densification affected their mechanical properties. Group 3 sintered at 950 ${ }^{\circ} \mathrm{C}$ resulted in higher hardness, density, and BFS values due to its lower porosity. Therefore, it is of utmost importance to follow the protocols recommended by the manufacturers of ceramics, including the times and temperatures to achieve the better properties for glass-ceramics. A sintering mistake can compromise the restorative material's performance such as reducing its mechanical strength and translucency due to a higher porosity, resulting in a weak and opaque material.

\section{Declarations of interest}

\section{None}

\section{Funding}

This study was partially supported by the Coordination for the Improvement of Higher Education Personnel (CAPES), Brazil - Finance Code 001, as well as for the São Paulo Research Foundation (FAPESP), grant \#2018/05736-9.

\section{Acknowledgments}

The authors are grateful to Thaís Paradela from the Institute of Science and Technology, São Paulo State University (Unesp) for the micrographs.

\section{REFERENCES}

1. Alkadi L, Ruse ND. Fracture toughness of two lithium disilicate dental glass ceramics. J Prosthet Dent. 2016;116:591-6. doi:10:1016/j. prosdent.2016.02.009

2. Apel E, Deubener J, Bernard A, Höland M, Müller R, Kappert H, et al. Phenomena and mechanisms of crack propagation in glass-ceramics. J Mech Behav Biomed Mater. 2008;1:313-25. doi:10.1016/j.jmbbm.2007.11.005

3. Apel E, Hoen C Van, Rheinberger V. Studies of crystal phase formations in high-strength lithium disilicate glass - ceramics. J Non Cryst Solids. 2006;::4041-50. doi:10.1016/j.jnoncrysol.2006.06.039.

4. Campos TMB, Ramos NC, MacHado JPB, Bottino MA, Souza ROA, Melo RM. A new silica-infiltrated Y-TZP obtained by the sol-gel method. J Dent. 2016;48:55-61. doi:10.1016/j.jdent.2016.03.004.

5. Dittmer M, Ritzberger C, Schweiger M, Rheinberger V, Wörle M, Höland W. Phase and microstructure formation and their in fl uence on the strength of two types of glass-ceramics. J Non Cryst Solids. 2013:1-6. doi:10.1016/j. jnoncrysol.2013.03.009.

6. Wange P,Höche T, Rüssel C, Dieter Schnapp J. Microstructure-property relationship in high-strength $\mathrm{MgO}-\mathrm{Al} 2 \mathrm{O3}-\mathrm{SiO2}$-Ti02 glass-ceramics. J Non Cryst Solids. 2002;298:137-45. doi:https://doi.org/10.1016/S00223093(02)00950-X.

7. Tulyaganov DU, Ribeiro MJ, Labrincha JA. Development of glass-ceramics by sintering and crystallization of fine powders of calcium-magnesiumaluminosilicate glass. Ceram Int. 2002;28:515-20. doi:10.1016/S02728842(02)00004-4.

8. Zhao T, Qin Y, Wang B, Yang JF. Improved densification and properties of pressureless-sintered lithium disilicate glass-ceramics. Mater Sci Eng A. 2015;620:399-406. doi:10.1016/..msea.2014.10.037.

9. Goharian P,Nemati A, Shabanian M, Afshar A. Properties, crystallization mechanism and microstructure of lithium disilicate glass-ceramic. J Non Cryst Solids. 2010;356:208-14. doi:10.1016/j.jnoncrysol.2009.11.015.

10. Dittmer M, Müller M, Rüssel C. Self-organized nanocrystallinity in MgO - Al 203 - Si0 2 glasses with Zr0 2 as nucleating agent. Mater Chem Phys. 2010;124:1083-8. doi:10.1016/.jmatchemphys.2010.08.037.

11. Fernandes HR, Tulyaganov DU, Goel IK, Ferreira JMF. Crystallization process and some properties of Li20-SiO 2 glass-ceramics doped with Al203 and K 20. J Am Ceram Soc. 2008;91:3698-703. doi:10.1111/.15512916.2008.02724.x.

12. Huang S, Cao P, Wang C, Huang Z, Gao W. Journal of Asian Ceramic Societies Fabrication of a high-strength lithium disilicate glass-ceramic in a complex glass system. Integr Med Res. 2013;1:46-52. doi:10.1016/j.jascer.2013.02.007.

13. Burgner LL, Weinberg MC. Assessment of crystal growth behavior in lithium disilicate glass. J Non Cryst Solids. 2001;279:28-43. doi:10.1016/S00223093(00)00325-2

14. Yuan K, Wang F, Gao J, Sun X, Deng Z, Wang H, et al. Effect of sintering time on the microstructure, flexural strength and translucency of lithium disilicate glass-ceramics. J Non Cryst Solids. 2013;362:7-13. doi:10.1016/j. jnoncrysol.2012.11.010.

15. Gaddam A, Fernandes HR, Ferreira JMF. Glass structure and crystallization of Al and B containing glasses belonging to the Li20-SiO2 system. RSC Adv 2015:5:41066-78. doi:10.1039/c5ra04184h.

16. Von Clausbruch SC, Schweiger M, Höland W, Rheinberger V. The effect of P205 on the crystallization and microstructure of glass-ceramics in the SiC2-Li20-K20-Zn0-P205 system. J Non Cryst Solids. 2000;263-264:38894. doi:10.1016/S0022-3093(99)00647-X. 
17. Cormier L. Nucleation in glasses - new experimental findings and recent theories. Procedia Mater Sci. 2014;7:60-71. doi:10.1016/j.mspro.2014.10.009.

18. Rüssel C, Keding R. A new explanation for the induction period observed during nucleation of lithium disilicate glass. J Non Cryst Solids. 2003;328:174-82. doi:10.1016/S0022-3093(03)00468-X.

19. Cividanes LS, Campos TMB, Bertran CA, Brunelli DD, Thim GP.Effect of urea on the mullite crystallization. J Non Cryst Solids. 2010;356:3013-8. doi:10.1016/j.jnoncrysol.2010.05.076

20. Khalkhali Z, Yekta BE, Marghussian VK. Preparation of lithium disilicate glass-ceramics as dental bridge material. J Ceram Sci Technol. 2014;5:3944. doi:10.4416/JCST2013-00030.
21. Höland W, Rheinberger VM, Ritzberger C, Apel E. Surface or internal nucleation and crystallization of glass-ceramics. Opt Mater. 2013;35:1756-8. doi:10.1016/j.optmat.2013.04.023.

22. Jacquin JR, Tomozawa M. Crystallization of lithium metasilicate from lithium disilicate glass. J Non Cryst Solids. 1995;190:233-7. doi:10.1016/00223093(95)00231-6.

23. Iqbal Y, Lee WE, Holland D, James PF. Metastable phase formation in the early stage crystallisation of lithium disilicate glass. J Non Cryst Solids. 1998;224:1-16. doi:10.1016/S0022-3093(97)00453-5.

24. Wang F,LiK, Ning C. Sintering properties of sol-gel derived lithium disilicate glass ceramics. J Sol Gel Sci Technol. 2018;87:372-9. doi:10.1007/s10971018-4738-3.

\section{Dayana Campanelli de Morais} (Corresponding address)

DDS, MSc. Department of Dental Materials and Prosthodontics, São Paulo State University (Unesp), Institute of Science and Technology, 777 Eng. Francisco José Longo Avenue, 12245-000, Sao Jose dos Campos, Brazil.

Email: dayanacampanelli@gmail.com

Date submitted: 2020 Jul 15

Accept submission: 2020 Sep 10 